\title{
Relation of migration trend and gender of RMG labour force in Industrial areas in Bangladesh
}

\author{
AKM Asaduzzaman Patwary \\ Jagannath University, Dhaka, Bangladesh
}

\begin{abstract}
Legitimate labour migration has, no doubt, got much attention in various economies and labour force irrespective of gender tempt for diverse employment. Industrial employment and job concentration in industrial cluster always provoke work driven migration. People relocate their whereabouts based on their secure livelihoods. And, economic centralization and targeted migration thus associate each other with no exception in Bangladesh. In the 5-decade long industrial history, many changes, reforms and challenges were noticed throughout our industrial ecosystem and labour dynamics. Labour force is a critical strength for efficient and low-cost productivity. In this regard, our mixed labour force, skilled, semi and unskilled workforce, has shaped our local industry and positioned as the most competitive regionally and contributed to gain productivity momentum and foreign trade growth. RMG industry, the forefront export-oriented sector of economy, has emerged as the largest employer of local migrated workforce of all contemporary industries in Bangladesh encouraging labour migration in urban area. This industry shares relatively large in GDP and export earning. With unprecedented contribution by RMG to economy, this study attempted to know whether any relationship of migration trend and gender status since this industry is a female dominant industry. The assessment of correlation is justifiably demanded due to women employment intensity since inception. But, this quantitative research-cause and effect study resulted that gender and migration condition and flow have no positive relationship and integration upon applying non-parametric test Chi-square test of significance. Around 252 independent samples from RMG factories in Dhaka and nearby districts where industrial hubs are located. It has obtained the null and rejected alternative hypothesis. These findings may help for national perspective planning and development planning. The drawn outcomes may also enable us national resource planning, mapping and human development index. As well, we can measure labour productivity in RMG industry and plan for future facility as well urban living and economic development.
\end{abstract}

Keywords: Multi Fibre Arrangement (MFA); Readymade Garments (RMG) sector.

\section{Introduction}

Labour migration is an important socioeconomic phenomenon in almost all developed and developing countries developed in the earlier years though trend in LDCs and developing countries are relatively more. Labour migration can be defined as influx and relocation of working people in an urban or economically vibrant areas or cities of any country. In most of the LDCs, where labor-intensive and capital backed industries developed that attracts low and unskilled workforces to migrate and embrace the new and available low-paid and employment opportunities. The emergence of RMG industry happened in Bangladesh later 2000 though life time of this business is almost four decades due to WTO Multi Fibre Arrangement (MFA) facility extended to Bangladesh and other LDCs. Bangladesh has always been endowed with abundance of inexpensive and unskilled labour which secures attention and demand of developed countries as the sourcing hub. Gradually, the growing concentration of US and European retailers on Bangladesh immensely built our local industrial base across the main cities thus paved the way of industrial cluster development. As main cities become crowded, more job seeking people moved and congregated in the urban areas for employment and living as well as featured with other living amenities. Thus, urban area became the centre of attraction to people for their survival. People in lower living standard have improved their condition, eradicated the poverty and other vulnerabilities faced in the poverty. The higher number of poor male and females once lived in rural areas and most of them struggled with poverty as limited formal employment opportunities as rural areas have very

* Corresponding author.

E-mail address: asaduzzaman@dhakachamber.com 
rare scopes of formal employment except some temporary and seasonal work attachments and full of unemployment. Rural economy has some agro-farming work scopes including cultivation and harvesting which allows more male engagements than females. As a s result, the hard hit and extreme poverty was seen and experienced in rural areas. The growing industrialization generated huge scopes for semi and unskilled people in diverse roles in RMG Industry. For the better and secure living and income, people heavily shifted to Dhaka, Chittagong and allied areas where these industries were set up thus urban living styles and trend and economy have changed. On the other hand, for overseas migration, each year, more than 400,000 workers exit Bangladesh for employment abroad (ILO, n.d.) The migration has extensively taken place. The economic migration has immensely grown, survived and eased the poverty, sufferings of common and poverty hit people. Alongside male, more females have joined the migration force and strengthened the migration spree. In Bangladesh, we have both in-country and cross-country migration in places. In our local industry, the in-pcountry migration rate looks richer as most of the industries are located in capital of country and adjacent areas as well as Chittagong second largest city and commercial city of country. Since RMG industry is led by female workforce and female and male workforce is seen 60:40, the migration trend from different parts of the country looks female dominant. Ullah (2007) showed that labor force participation rate of females in Bangladesh is high compared to female migrants in the selected Asian countries. With the growth of this industry, females and their dependents also got involved in this sector in different capacities. Thus, the influx of migration to urban areas have gone up. The large portion of the labor force in many factories in developing countries mostly sourced from internal migrants from rural areas, who have little information about the industry while they begin work (Boudreau, et.al 2018). It was presumed that women in this industry has established their position and more women of their kins and next relatives have moved in those areas for their better livelihood. Influence of families and relatives are also visible force for migration. It is often said that some industries have gender preference and concentration in employment. Therefore, it needs to check if gender wise any difference has been established in urban or industrial cities in course of industrial growth. And, the trend of gender led migration and industrial growth over the past decades needs to be assessed to find the association of them.

\section{Statement of the problem:}

Labour migration emerged as an important source of foreign reserve in Bangladesh and Government has taken several policy initiatives in mainstreaming migration as well as catering services according to the needs of the migrant workers in the country (ILO, 2019). Apart from outbound or international migration, the local migration in-country migration has taken place since independence. Conventionally, urban areas are richer than rural areas in economic strength as a result, labour migration to urban area is a continuous process. Bangladesh conventionally until becomes a developing economy witnessed a gap between rural and urban economy which creates and insisted people in poverty to migrate to urban areas for livelihood irrespective of planned and unplanned employment. People moved to cities for informal and formal sector employment in most instances they ended up in different labor-intensive industries in urban areas. The unplanned industrialisation and economic activities accommodated huge number of migrated people and helped for subsistent living and survivals. This is how urban and rural economic connectivity and network established. Urbanization and urban economy thus contributing to rural economic growth. This culture and survival of vulnerable people created instances and examples for RMG to accommodate more helpless people. Since RMG industry performed well among all other labor-intensive industries, it attracted more low skilled employment and migration over the past years. And, most rural females and males made planned shift in urban areas in capital and industrial cities for RMG sector jobs. Thus, this trend become more popular as this industry made steady growth up unit today. In-country migration has become popular over the time and means of poverty alleviation in Bangladesh. Irrespective of gender, people moved to urban areas for employment and survival. The income through employment in RMG industry has also contributed to reduce rural poverty and rural economic growth reducing rural and urban income disparity. Migration has many positive features and effects that brought various socioeconomic changes and impacts in the country. Gender wise migration scenario shows rate of male migration is higher than female but this scenario does not prevail across all sectors and industries. RMG industry has been the largest employer and around 4 million workforces since early 2000 onwards and dependent on this sector. After several disasters in 2013 and 2012, the many owners stopped business and pulled out investment and reduced the number of factories due to unavoidable cost of compliance and safety issues. As well mechanization, moderanisation also took place and reduced some employment opportunities though helped productivity and efficiency. However, the overall workforce size has reduced to around 3.5 million. Despite this decline in the workforce number, the industry is led by women and migrated workforces. Out of 8 divisions of Bangladesh, the migration continues due to family and peer references as this industry has structed minimum wage scale and better work condition. Since it is grossly a sewing and fashionwear industry, women are more tempted to work and has developed as the women intensive industry. The 
migration has helped to source substantial amount of workforce and support the smooth growth of the RMG industry. RMG workforce and working environment and frequent growth and contribution to economy sizably helped. The RMG industry is the largest export earning industry and single largest industrial sector with $13 \%$ contribution to GDP. This study would identify how the gender of migration in RMG industry took place and whether the gender difference has impact on the growth of this industry. We are required to know if there is any association between gender and RMG industry labour migration in Bangladesh. The trend of gender state of workforce migration into RMG industry in past years needs to be seen. Thus, effect and influence of gender may be measured and assessed.

\section{Literature Review}

Islam \& Siddiqui (2010) explored the association significantly between migration and socio-demographic characters like marriage, education, religion, living conditions. In the beginning of 21st century, 1 in every 34 persons worldwide was international migrant which has changed. United Nations found total number of international migrants was around 175 million (UN, 2002).

It is increasingly acknowledged that migration is a highly gendered phenomenon. Women face different challenges and opportunities in many areas than similarly situated men do. In addition, because rural women still often lack access to infrastructure and productive resources, as world's most illiterate adults, are not included in waged employment from urban women. Rural women, decide to migrate or stay behind as family members of male migrants, are confronted with very specific hardship that both migration and development need attention. Rural women and rural working women in urban area are not from homogenous groups due to circumstances, migration capacity, plan and control their journey as well as its outputs, vary for their income, social connection and family condition (Danziger, 2009).

Climate change, economic restructuring and industrialisation led to huge loss of traditional livelihoods, agricultural activities, environmental degradation, wage stagnation and precarious work growth- resulting in inequality and forcing women for alternative income generating activities, including through work migrations. (Sultana, et.al. 2018).

Same workforce receives uneven compensation in different firms in (Krueger and Summers 1988; Brown and Medoff 1989; Abowd, Kramarz and Margolis 1999) and developing (Strobl Walsh, 2008) in different economies. Heterogeneity is greater in developing countries where government and market imperfections steer inefficient firms (Banerjee and Duflo, 2005). Certain workplace safety and other protection regulations for workers further contribute to different sectors in terms of wage and non-wage benefits (Boudreau et .al, 2018) in developing countries. Alongside, the large number of labor force in many factories in developing countries consists of internal migrants from rural areas, who may have little information about the industry while begin job. Firms compete for informed workers (who can observe working conditions upon beginning a job) and uninformed workers. The uninformed workers end up in firms with inefficiently low investments in working conditions - even in a competitive labor market - as firms compete for workers based on job aspects, they can see in wage gap and other aspects of working conditions which they cannot witness. In this model, workers are mostly weak and uninformed workers. We also considered several potential differences between internal migrants and local workers. The labor outcomes across the careers of migrants and locals, corresponding to the predictions in the given model. Lewis (1954) and Harris and Todaro (1970) argued average urban workers are more productive than rural areas and rural to urban migration has been considered as key driver of economic growth.

Shoncchoy (2017) found in a study of RMG sector that factories are concentrated in the Dhaka and Chittagong have majority, $85 \%$ of migrant garment workers from elsewhere in the country though their distribution by source region is not same. The growing number of migrants that strengthen our garment workforce is a result of the "fast fashion trend' which shaped our industries. Retailers offer faster changing collection for bargain prices and that require cheap production sources with low prices and lead time in the textile and garment industry. The benefits and working conditions faced by migrant workers are not different from the local labour force in the global Apparel and textile industry. They are often deprived from freedom of association and pay discrimination (Somo, 2016). Dannecker (2005) found that the successful exploitation of global markets by female migrants has not only resulted in new migration patterns and gendered labour market but became labour transformation. 
Lewis (1954), Harris and Todaro (1970) argued that workers are on average more productive in urban than rural areas, so urban migration is a key driver of economic growth. Other considerable assessment showed that internal migration affects wages and benefits in urban labour markets (Kleemans, Magruder 2015, Strobl \& Valfort 2015).

The literature reviewed shows migration has been an important factor across the world irrespective of developed and developing economies and that trend continues. In the LDC countries outward and in-country migration trend is more prevalent and visible. But no study was referred and found out of the relevant assessment that impact and nexus of gender led migration and industrial change in Bangladesh happened. This demands a critical assessment of labour migration and gender in country's leading export-oriented industry.

\subsection{Research question}

After the review of all relevant literation, we found that it needs to be established whether there is any relation of RMG workforce migration and gender issue seen.

\subsection{Objective of the study}

- To define the state of labour migration in urban areas for employment.

- To analyse the significance and relation of gender issue and migration in RMG industry.

\subsection{Hypothesis of the study}

There is no relation or association of labour migration and gender denoted as $\mathrm{H} 0=0$ or H1Migration: Gender as the null hypothesis.

And, alternative hypothesis is $\mathrm{H} 1 \neq 0$ means there is significant association between the state of gender and migration within the industry.

\section{Research Method}

This is a quantitative and cause and effect assessment study. Cluster sampling technique has been applied. And, sample units are both male and females and around 252 RMG employees have been chosen from the relevant workforce.

The sample unit was chosen using convenience sampling technique which is non-random and non-distributed. Factories were shortlisted and chosen from Dhaka, Savar and Gazipur which are large industrial hubs especially for textile and RMG sector covering substantial RMG industrial zones and clusters of the country. However, clusters techniques were also some extent considered as RMG industries and associated businesses also developed within these regions and areas.

The data analysis has been made using descriptive data analysis technique. For primary data analysis, the chi-square technique, the non-parametric test tool has been used as well for the test of significance. And, this is a distribution free test. This will be tested at $95 \%$ level of significance. SPSS 20 and Microsoft Excel were used to code, tabulate and process the given data.

\section{Findings of the Data Analysis}

\subsection{Descriptive analysis of the assessment}

Total 252 workforce as samples was considered in this study. Total samples used in the given study resulted as follows:

The migration rate was around $94.8 \%$ and non-migration was around $5.2 \%$ found the frequency table 1 of the given study shown. 
Table 1. Gender of the respondent

\begin{tabular}{|c|c|c|c|c|c|}
\hline & & Frequency & Percent & Valid Percent & $\begin{array}{c}\text { Cumulative } \\
\text { Percent }\end{array}$ \\
\hline & male & 121 & 47.3 & 47.6 & 47.6 \\
\hline Valid & female & 133 & 52.0 & 52.4 & 100.0 \\
\hline & Total & 254 & 99.2 & 100.0 & \\
\hline $\begin{array}{l}\text { Missing } \\
\text { Total }\end{array}$ & System & $\begin{array}{r}2 \\
256\end{array}$ & $\begin{array}{r}.8 \\
100.0\end{array}$ & & \\
\hline
\end{tabular}

The following figures depicts that $47.6 \%$ are male around 121 and $52.45 \%$ are female around 133 in the given assessment out of the total number of samples considered.

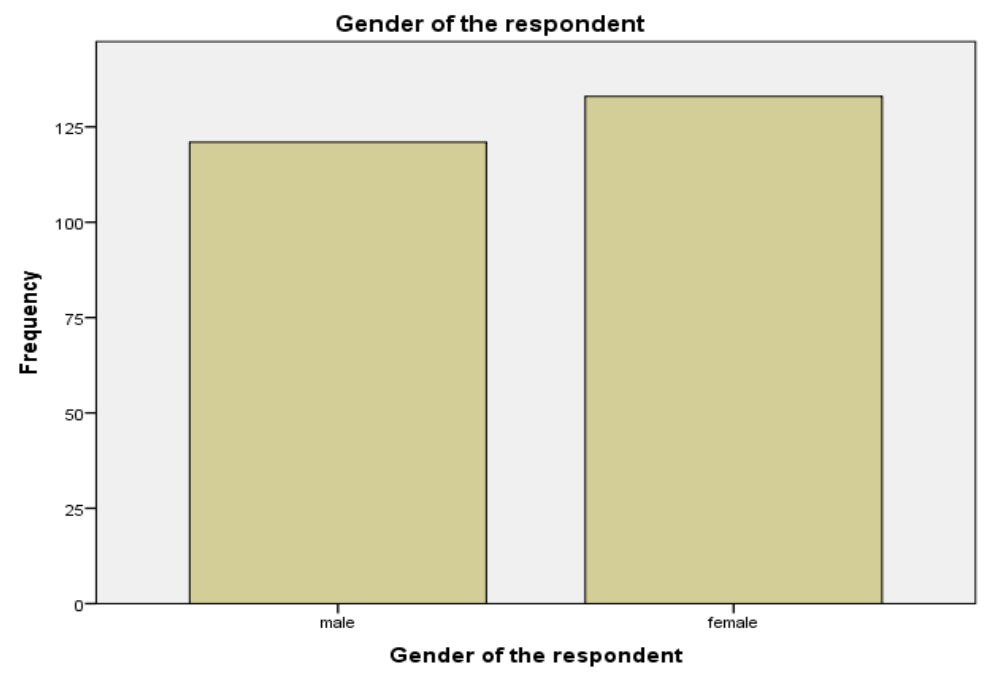

Figure 1. Gender of the respondent

On the other hand, the other bar diagramme of the migration shows that of the total sample units, $5.2 \%$ have no migration and remaining $94.8 \%$ have migrated from different places or districts.

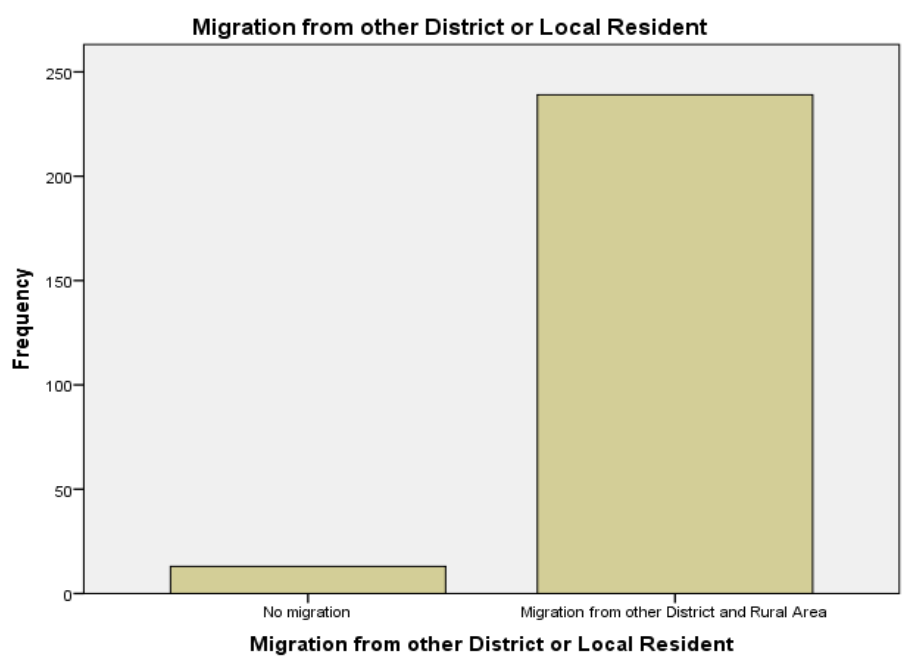

Figure 2. Migration from other District of Local Resident 
Table 2. Migration from other District or Local Resident * Gender of the respondents Cross-tabulation

\begin{tabular}{|ll|r|r|r|}
\hline & & \multicolumn{2}{|c|}{ Gender of the respondent } & \multicolumn{2}{|c|}{ Total } \\
\cline { 3 - 4 } & \multicolumn{2}{|c|}{ male } & female & \\
\hline Migration from other & No migration & 5 & 13 \\
District or Local Resident & Migration from other & 114 & 125 & 239 \\
Total & District and Rural Area & 119 & 133 & 252 \\
\hline
\end{tabular}

The observed and expected number for female and male migration are different.

Upon assessment of the primary data of the RMG sector labour force in the targeted region, we applied the ChiSquare test and Crammer's V application and phi for assessing the test of significance. But, the result of 200 RMG workforce data shown there is no test of significance in the Gender and labour migration to urban industrial area.

Table 3. Chi-Square Tests

\begin{tabular}{|c|c|c|c|c|c|}
\hline & Value & $\mathrm{df}$ & $\begin{array}{l}\text { Asymp. Sig. (2- } \\
\text { sided) }\end{array}$ & $\begin{array}{l}\text { Exact Sig. (2- } \\
\text { sided) }\end{array}$ & Exact Sig. (1-sided) \\
\hline Pearson Chi-Square & $.422^{\mathrm{a}}$ & 1 & .516 & \multirow{6}{*}{.579} & \multirow{6}{*}{.360} \\
\hline Continuity Correction ${ }^{\mathrm{b}}$ & .133 & 1 & .716 & & \\
\hline Likelihood Ratio & 427 & 1 & .514 & & \\
\hline Fisher's Exact Test & & & & & \\
\hline $\begin{array}{l}\text { Linear-by-Linear } \\
\text { Association }\end{array}$ & .420 & 1 & .517 & & \\
\hline $\mathrm{N}$ of Valid Cases & 252 & & & & \\
\hline
\end{tabular}

a. 0 cells $(0.0 \%)$ have expected count less than 5 . The minimum expected count is 6.14 .

b. Computed only for a $2 \times 2$ table

Table 4. Symmetric Measures

\begin{tabular}{|ll|r|r|r|r|}
\hline & & \multicolumn{1}{|c|}{ Value } & $\begin{array}{c}\text { Asymp. Std. } \\
\text { Error }^{\mathrm{a}}\end{array}$ & Approx. $\mathrm{T}^{\mathrm{b}}$ & Approx. Sig. \\
\hline \multirow{3}{*}{ Nominal by Nominal } & Phi & -.041 & & & .516 \\
& Cramer's V & .041 & & & .516 \\
& Contingency Coefficient & .041 & & & .516 \\
Interval by Interval & Pearson's R & -.041 & .062 & -.648 & $.518^{\mathrm{c}}$ \\
Ordinal by Ordinal & Spearman Correlation & -.041 & .062 & -.648 & $.518^{\mathrm{c}}$ \\
N of Valid Cases & & 252 & & & \\
\hline
\end{tabular}

a. Not assuming the null hypothesis.

b. Using the asymptotic standard error assuming the null hypothesis.

c. Based on normal approximation.

The Pearson Chi-square value is .422 and $\mathrm{P}$ value is greater than .05 as recorded .516 . On the other hand, the phi and Cramers' $\mathrm{V}$ also result .516 which is also insignificant in value. The assumption and Null hypothesis of no relation of gender and migration is not rejected.

The result does not support the alternative hypothesis of the study.

The brief of test results can be enumerated that there is no significant relation of gender and industrial migration proven in the given study.

Usually, Phi and Cramer's V indication are followed once more than 2 categorial or nominal variables are considered in a given study. In this study, this has not been followed. The expected count is seen 6.14 which is at acceptable level. 


\subsection{Contribution to policy reforms}

- The migration is a never-ending process within an economy and the rate is higher in the developing country. The trend can be minimum once the gap rural and urban poverty can be minimised. The urban development planning and mapping can be eased with migration trend.

- Industrial growth, labour productivity and efficiency can be measured. Migration and socioeconomic impact can be measured in manufacturing industry in Bangladesh.

- Human development planning and index can be done properly with inclusive development plan.

- National budget and living wage and rational allocation of budget can be examined through gender led migration assessment.

- Human census and industrial growth and contribution of migrated labour force to industrial mobility can be measured and impact RMG industry to social context can be identified.

- Industrial clusters like EPZs across the country have developed some communities in major towns in Bangladesh thus economic activities expanded. The urban planning and citizens living facilities may be planned as more town clusters will develop due to 100 planned economic zones across the country.

- $\quad$ The study found no established statistical significance of gender and migration trend which means irrespective of gender any professional can adopt migration if needed for their livelihood. This will help to determine future RMG workforce concentration mapping for any major planning in this industry.

\section{Conclusion}

The study is undertaken to show the relation of migration and Gender status in our reputed RMG industry, the lifeline of international trade and local industry. However, though there has been a positive trend of employment and job growth was noticed led by female workforce but significant correlation of gender and migration has not proven. The low-cost labour and women concentration in this industry marched growth of this industry with positive impacts in the economy in the past decades. The industry was seen performing remarkably in many areas and fronts especially in women employment and gender gap reduction, income and social disparity cut as well leading the basis of inclusive industrial development in Bangladesh. RMG industry has created opportunities and learning for manufacturing sectors to create a gender friendly work place. As a result, other export-oriented manufacturing sectors like Jute goods, Leather and Chemical, Agricultural products paved the way for women employment generation and reduced personal and family poverty who migrated in urban areas and received industrial livelihood. However, the study has justified how migration has expanded the industrial capacity and productivity through abundance of work force and generation of cost-efficient production but this study has not proven the gender sensitive migration considering the industrial labour state. The labour force and gender state in the much-discussed RMG industry in Bangladesh has no evidence of strong association and relevance but migration has got huge impact in the industrial ecosystem of the country was evident undoubtedly and critically in various research studies held earlier in Bangladesh and other economies. Thus, we can visualize the industrial migration picture and dynamics of Bangladesh from the gender perspective.

\section{References}

Banerjee, A. V.,\& Duflo, E. (2005). Growth theory through the lens of development economics. Handbook of economic growth, 1: 473-552.

Boudreau, L., Heath, R., \& McCormick, T. (2018). Migrants, Information, and Working Conditions in Bangladeshi Garment Factories, paper-march-2018.pdf.

Dannecker, P. (2005). Transnational Migration and the Transformation of Gender Relations: The Case of Bangladeshi Labour MigrantsTransnational Migration and the Transformation of Gender Relations: The Case of Bangladeshi Labour Migrants. DOI: https://doi.org/10.1177/0011392105052720

Danziger, N. (2009). "Rural and women migration". IoM available at https://www.iom.int/sites/g/files/tmzbdl486/files/migrated_files/What-We-Do/docs/Rural-Women-andMigration-Fact-Sheet.pdf.

Florida International University, https://www.theigc.org/blog/barriers-labour-migration-bangladeshs-garment-sector/. 
Harris, John R, Michael, P, Todaro. (1970). “Migration, unemployment and development: a two-sector analysis.” The American Economic Review, 60(1): 126-142.

ILO (2019). "The mapping and scoping of services for the Migrant workers of Bangladesh at various stages of labour migration cycle", retrieved from http://ilo.ch/dhaka/Whatwedo/Publications/WCMS_686953/lang-en/index.htm.

ILO (n.d.) https://www.ilo.org/dhaka/Areasofwork/labour-migration/lang--en/index.htm

Islam, S. MNA. (2010). Socio-demographic characteristic of female migrants and determinants of female migration. Afro Asain Journal of Anthropology.

Kleemans, M., \& Magruder, J. (2015). "Labor market changes in response to immigration: evidence from internal migration driven by weather shocks." Unpublished manuscript.

Krueger, Alan B, \& Summers, L. H. (1988). "Efficiency wages and the interindustry wage structure.” Econometrica: Journal of the Econometric Society, 259-293.

Lewis, W. Arthur. (1954). "Economic development with unlimited supplies of labour." The manchester school, 22(2): 139-191.

Shamim, I. (2002). Feminization of Trafficking: The Nexus Between Supply and Demand in South Asia. Paper presented in the International Conference on The Human Rights Challenge of Globalization in Asia-PacificUS: The Trafficking in Persons, Especially Women and Children, Honolulu, Hawaii, USA, 13-15 November.

Shonchoy, A. (2017). Barriers to labour migration in Bangladesh's garment sector,

Somo (2016). Fact Sheet Migrant labour in the textile and garment industry A focus on the role of buying companies.

Strobl, Eric, \& Valfort. M. A. (2015). "The effect of weather-induced internal migration on local labor markets. Evidence from Uganda." The World Bank Economic Review, 29(2): 385-412.

Sultana, S., Rabbani, R., Islam, R., Tithi,F. (2018).Safe and Fair Migration from the Perspective of Women Migrant Garments Workers (WMGW) in Bangladesh KarmojibiNari (KN) www.karmojibinari.org.

Ullah, AKMA. (2007). The state of female migration flow in international labour market: how is Bangladesh doing? Available in Website www.hull.ac.uk/php/ecskrb/GDP2007/Ullah.pdf. 